\title{
Endocannabinoids are involved in male vertebrate reproduction: regulatory mechanisms at central and gonadal level
}

\section{Patrizia Bovolin $1,2 *$, Erika Cottone ${ }^{1}$, Valentina Pomatto ${ }^{1}$, Silvia Fasano ${ }^{3}$, Riccardo Pierantoni ${ }^{3}$, Gilda Cobellis ${ }^{3 \dagger}$ and Rosaria Meccariello ${ }^{4}$}

${ }^{1}$ Department of Life Sciences and Systems Biology, University of Turin, Turin, Italy

${ }^{2}$ Neuroscience Institute of Turin, University of Turin, Turin, Italy

${ }^{3}$ Dipartimento di Medicina Sperimentale, Seconda Università di Napoli, Naples, Italy

${ }^{4}$ Dipartimento di Scienze Motorie e del Benessere, Università di Napoli Parthenope, Naples, Italy

\section{Edited by:}

Yong Zhu, East Carolina University, USA

\section{Reviewed by:}

Paola Piomboni, University of Siena, Italy

Paola Grimaldi, University of Rome Tor Vergata, Italy

\section{*Correspondence:}

Patrizia Bovolin, Department of Life

Sciences and Systems Biology,

University of Turin, via Accademia

Albertina 13, 10123 Turin, Italy

e-mail: patrizia.bovolin@unito.it

${ }^{+}$Gilda Cobellis and Rosaria

Meccariello have contributed equally to this work.
Endocannabinoids (eCBs) are natural lipids regulating a large array of physiological functions and behaviors in vertebrates. The eCB system is highly conserved in evolution and comprises several specific receptors (type-1 and type-2 cannabinoid receptors), their endogenous ligands (e.g., anandamide and 2-arachidonoylglycerol), and a number of biosynthetic and degradative enzymes. In the last few years, eCBs have been described as critical signals in the control of male and female reproduction at multiple levels: centrally, by targeting hypothalamic gonadotropin-releasing-hormone-secreting neurons and pituitary, and locally, with direct effects on the gonads. These functions are supported by the extensive localization of cannabinoid receptors and $\mathrm{eCB}$ metabolic enzymes at different levels of the hypothalamic-pituitary-gonadal axis in mammals, as well as bonyfish and amphibians. In vivo and in vitro studies indicate that eCBs centrally regulate gonadal functions by modulating the gonadotropin-releasing hormone-gonadotropin-steroid network through direct and indirect mechanisms. Several proofs of local eCB regulation have been found in the testis and male genital tracts, since eCBs control Sertoli and Leydig cells activity, germ cell progression, as well as the acquisition of sperm functions. A comparative approach usually is a key step in the study of physiological events leading to the building of a general model. Thus, in this review, we summarize the action of eCBs at different levels of the male reproductive axis, with special emphasis, where appropriate, on data from non-mammalian vertebrates.

Keywords: GnRH, hypothalamus, pituitary, spermatogenesis, chromatin remodeling, male fertility

\section{INTRODUCTION}

Since the discovery of $\Delta^{9}$-tetrahydrocannabinol (THC) as the main psychoactive ingredient in marijuana, the subsequent cloning of cannabinoid receptors and the identification of their endogenous ligands [i.e., endocannabinoids (eCBs)], our understanding of the functions of the eCB system (ECS) has evolved considerably. It has become evident that most components of the mammalian ECS are highly conserved in evolution, pointing to a fundamental modulatory role in basic cellular and organismic functions $(1,2)$. Accordingly, the ECS is widely expressed in vertebrates, central and peripheral organs, and regulates a large array of physiological functions and behaviors.

The basic eCB signaling system consists of (1) at least two G-protein-coupled receptors, known as the cannabinoid type-1 and type-2 receptors (CB1 and $\mathrm{CB} 2)$; (2) the endogenous ligands, of which anandamide (AEA) and 2-arachidonoylglycerol (2-AG) are the best characterized; and (3) synthetic and degradative enzymes and transporters that regulate eCB levels and action at receptors. $\mathrm{CB} 1$ receptors are abundant in the whole vertebrate central nervous system (CNS) and some peripheral tissues (3-5), whereas CB2 receptors are mostly expressed in peripheral tissues and immune cells, but they have recently been found also in the CNS (6-8). Research in mammals has provided evidence that eCBs can also bind to and activate type-1 transient receptor potential vanilloid (TRPV1) channels (9).

An enormous amount of information on the general properties of the ECS has accumulated over the last two decades [for general reviews on the ECS, see Ref. (10-14)]. In the past years, growing evidence has been accumulating to show the central role of the ECS in controlling vertebrate reproductive functions at both central and gonadal level (15). This review will summarize the action of eCBs at different levels of the reproductive axis, including data from non-mammalian vertebrates.

\section{EFFECTS OF ECBS ON HYPOTHALAMIC-PITUITARY CONTROL OF REPRODUCTION}

Reproductive functions are under neuroendocrine control and require a tight crosstalk between the hypothalamus, pituitary, and gonads. Gonadotropin-releasing-hormone $(\mathrm{GnRH})$ is a key molecule in reproductive behavior and physiology. This neuropeptide 
is synthesized by hypothalamic neurons mostly located, in mammals, in the preoptic area and in the arcuate nucleus. GnRH axons project to the median eminence, where pulsatile release of $\mathrm{GnRH}$ into the hypophysial portal circulation drives the synthesis and secretion of follicle-stimulating hormone (FSH) and luteinizing hormone (LH) from anterior pituitary gonadotropic cells. Circulating FSH and $\mathrm{LH}$, in turn, stimulate gametogenesis and the synthesis and secretion of the gonadal steroid hormones, androgens, estrogens, and progesterone. Under various physiological and pathological conditions, hormonal and metabolic signals regulate $\mathrm{GnRH}$ neurons both directly or through upstream neuronal circuitries to influence the pattern of GnRH secretion. The emerging picture from studies in different vertebrate models is that eCBs can modulate both GnRH and gonadotropic cell function, in other words that eCBs can influence the regulation of reproduction at both hypothalamic and pituitary levels $(16,17)$.

There is general agreement on the inhibitory effect exerted by cannabinoids and eCBs on $\mathrm{GnRH}$ release. Early studies in rats demonstrated that the ECS influence gonadal androgens via effects on the hypothalamus and the anterior pituitary. THC, as well as eCBs, lowers not only circulating testosterone levels but also the levels of LH and FSH (18). Most of this negative effect appears to be exerted by inhibition of GnRH secretion into median eminence blood portal vessels $(19,20)$. Serum LH decreases in response to AEA administration in wild-type mice, whereas CB1 knockout mice $\left(\mathrm{Cb1}^{-/-}\right)$are unresponsive to the treatment (21) and show low levels of GnRH and FSH-beta mRNA at hypothalamic and pituitary levels (22), demonstrating the pivotal role exerted by $\mathrm{CB} 1$ in the regulation of $\mathrm{GnRH}$ and godanotropins synthesis and/or release.

The above effects require CB1 expression in ventro-medial telencephalic and hypothalamic regions. Early localization studies in rodents detected a low abundance of CB1-immunoreactive axons (23) and a low expression level of CB1 mRNA (24-26) in the rodent hypothalamus. However, more recent immunocytochemical studies (27) revealed a dense CB1-immunoreactive fiber network in the mouse hypothalamus. These data are consistent with studies in teleosts and amphibians, showing the expression of CB1-immunoreactive fibers and cell bodies in several hypothalamic regions of adult teleosts (Carassius auratus and Pelvicachromis pulcher) and anuran amphibians (Xenopus laevis and Rana esculenta) $(4,5,28,29)$, as well as in zebrafish and in embryos of $X$. laevis $(30,31)$. The expression of $C B 1$ appears to be regulated in the diencephalon during the annual sexual cycle in anuran amphibians (32). Interestingly, CB1 fluctuations show an opposite trend compared to $G n R H-I$ mRNA variations, suggesting that maximal GnRH release corresponds to minimal CB1 levels in the diencephalon. Both $G n R H-I$ and $G n R H-I I$ expressions are inhibited in the frog diencephlaon by AEA administration, indicating that both molecular forms might be involved in the regulation of gonatropin discharge (33). Only few data so far indicate that CB2 and TRPV1 receptors might have a role in GnRH cell regulation. Profiling neurotransmitter receptor expression in mouse GnRHsecreting neurons revealed CB2 expression in diestrous adult females (34), and CB1/TRPV1 co-localization has been reported in mouse hypothalamic paraventricular nucleus (35).
An important question is whether eCBs exert their effect directly on GnRH neurons, or on neighboring cells that control $\mathrm{GnRH}$ release. Gammon et al. (36) demonstrated that immortalized GnRH neurons (GT1 cells) are both a source and target of eCBs; they produce and secrete 2-AG and AEA, are able to take up and degrade eCBs, and possess $\mathrm{CB} 1$ and $\mathrm{CB} 2$, whose activation leads to the inhibition of pulsatile GnRH release. Nevertheless, such observations have not been confirmed in vivo in mammals, although GnRH-secreting neurons are close to cannabinergic fibers in male mice (37) and few hypothalamic GnRH neurons seem to express CB1 receptors (36). Close proximity between CB1expressing fibers and GnRH cells has been well documented in non-mammalian vertebrates. In P. pulcher, C. auratus, Solea solea, and Danio rerio, CB1-containing cell bodies and terminals codistribute with GnRHIII (also called salmon GnRH) cell bodies and fibers (38-40). Similarly, codistribution of CB1- and GnRH-Iimmunoreactivity has been found in corresponding brain regions of X. laevis and R. esculenta $(39,41)$. Noteworthy, a subset of frog GnRH-I-immunoreactive neurons in the septum and preoptic area are also CB1 immunopositive (28), suggesting the existence of a CB1-mediated autocrine mechanism in the control of $\mathrm{GnRH}$ secretion, in addition to presynaptic mechanisms. Ultrastructural studies in mammals indicate that CB1-immunoreactive terminals establish symmetric as well as asymmetric synapses on GnRH neurons, suggesting that retrograde $\mathrm{eCB}$ signaling might influence GABAergic and glutamatergic synaptic transmission, respectively (27). It should be noted that most recent studies examining the effects of endogenous GABA release on GnRH neurons indicate that the predominant action is that of excitation (42). In line with this, Farkas et al. (37) provided electrophysiological and morphological evidence that retrograde eCB signaling reduces GABAergic excitatory drive onto GnRH neurons via activation of presynaptic $\mathrm{CB} 1$ receptors, and that the reduced $\mathrm{GABA}_{\mathrm{A}}$ receptor signaling in turn inhibits GnRH neuron firing activity. Besides the major afferent regulation exerted on GnRH neurons by GABAergic and glutamatergic inputs, available neuroanatomical literature describes afferent inputs by peptidergic and monoaminergic neuronal systems (43). However, whether the ECS interacts also with these systems has not been determined yet.

Besides the effect on GnRH cells, eCBs could also modulate the activity of other hypothalamic cell types involved in reproduction. Cells containing aromatase, the enzyme that catalyzes the transformation of androgen into estrogens, are localized in the hypothalamus and are deeply involved in sexual differentiation of the brain and activation of male sexual behavior. Aromatase and $\mathrm{CB} 1$ are expressed in close contiguity in the goldfish preoptic area and periventricular gray of hypothalamic inferior lobes (16), suggesting a possible CB1-mediated regulation of aromatase activity, at least in bony fish.

Several lines of evidence indicate that eCBs may control adenohypophyseal hormone secretion also acting directly at pituitary level. Both AEA and 2-AG have been detected in the anterior pituitary, suggesting local synthesis (44). In addition, CB1 has been localized in the anterior pituitary within the gonadotroph and lactotroph cells in adult male rats $(45,46)$, in humans $(47)$, and in $X$. laevis (48). CB1 expression in pituitary depends on steroids, 
since it is reduced in both orchidectomized male and estradiolreplaced OVX female rats (46). Recently, the presence of ECS has been demonstrated in mammalian pars tuberalis (49). This finding might be functionally significant also for $\mathrm{GnRH}$ release, since this pituitary region is a key station for the anterograde signaling toward the pars distalis.

\section{EFFECTS OF eCBs AT GONADAL LEVEL}

Beside the role exerted at hypothalamic level to control reproductive activity in both sexes, the discovery of eCBs in gonads and reproductive fluids - from seminal plasma in males to oviductal fluid and milk in females - (50-52) pointed out the importance of eCB signaling in the gonads. Gonads have the ability to synthesize eCBs which in turn exert differential effects activating both different types of receptors or tissue-/cell-specific receptor subtypes, the latter obtained by both alternative splicing or transcription sites (53-55). The content of eCBs is regulated by biosynthetic/hydrolyzing enzyme balance, and the appropriate "eCBs tone" in loco, is critical for spermatogenesis progression in male and follicle maturation in female, for sperm quality and the acquisition of sperm functions related to fertilization (motility and capacitation), for fertilization, early-embryo migration, implantation and placentation, for parturition onset and labor as well (15, 17, 56-63). Focusing on males, evidence of eCB direct action into the testis has been provided in most vertebrates [fish $(8,64)$, frogs (32, 57, 65-68), mammals $(21,69-74))$, whereas an ECS has also been described in spermatozoa (SPZ) collected from sea urchin (75), amphibians (65), rodents (76-79), bull (80), boar (81), and human (82-85). A specific and significant association between the use of marijuana and the occurrence of non-seminomatous and mixed testicular germ cell tumors (TGCT) has been recently reported in humans (86-88); although a deep characterization of ECS has never been provided in TGCT patients yet, these data may suggest that the recreational and therapeutic use of cannabinoids may represent a risk factor for TGCT. In general, a relationship between the expression of cannabinoid receptors and the outcome of sex-steroid-dependent cancer has been documented, thus the imbalance in the ECS and its interaction with sex-steroid hormone homeostasis may promote cancer development, proliferation, and migration [for recent review, see Ref. (89)]. Defects in eCB signaling or eCB tone have recently been reported in rat treated with HU210 - a synthetic analog of THC - (90) as well as in clinical cases of male infertility in humans $(85,91)$. Consistently, genetic inactivation of the AEA-hydrolyzing enzyme, Faah (Fatty acid amide hydrolase) results in increased levels of AEA in the male reproductive system that negatively affect sperm motility and impair sperm fertilizing ability (92), whereas defects in the acquisition of sperm motility during the epididymal transit have been reported in $\mathrm{Cb1}^{-1-}$ mice $(76,77)$. Thus, ECS is nowadays considered a potential therapeutic target in male infertility. ECS is widely expressed in testis in both germ and somatic cells, and a map of ECS localization in several species is provided in Table 1. The first intratesticular targets of eCBs to be identified were the Leydig cells $(21,93)$, consistent with the low basal testosterone production observed in both $\mathrm{Cb}^{-1-}$ mice and AEA-treated controls, providing evidence of mechanisms other than the AEA/THC-dependent downregulation exerted at hypothalamic/pituitary levels. The direct effect of
Bhang (cannabis) on 3 $\beta$-HSD, a well-known marker of Leydig cell activity, also confirmed this issue (79). The involvement of CB1 signaling in the control of Leydig cell activity is not restricted to steroid (both testosterone/estradiol) production (21, 22, 93), but also extends to Leydig cells ontogenesis. In fact, as reported by Cacciola et al. (72), CB1 expression in differentiating adult Leydig cells negatively correlates with cell division and the characterization of $\mathrm{Cb}^{-1-}$ mice phenotype revealed a 30\% decrease in Leydig cells number (72), as well as low circulating estradiol level (22) [for recent review, see Ref. (94)].

In the germinal compartment, AEA reduces the spermatogenic output inducing the apoptosis of Sertoli cells (70) in a mechanism reversed by FSH-dependent activation of aromatase and by estradiol-dependent upregulation of Faah (71). Recent studies carried out by Grimaldi et al. (95) demonstrated that in mature Sertoli cells Faah gene is a direct target of estradiol whose promoter contains two proximal estrogen-responsive element (ERE) sequences named ERE2/3. In vivo, a mechanism involving the binding of ER $\beta$ to ERE $2 / 3$ and the epigenetic modifications of Faah gene proximal promoter (demethylation of both DNA at CpG site and histone H3 at lysine 9) has been demonstrated (95); consistently FAAH silencing abolished estrogen protection against AEA-dependent apoptosis (95). Thus, AEA content finely toned by its hydrolyzing enzyme FAAH is a fundamental tool to prevent the apoptosis in Sertoli cells.

Beside the activity exerted on Sertoli cells, eCBs are critical for the progression of spermatogenesis from mitotic stages throughout the meiotic stages and spermiogenesis events. In such a context, the FAAH-dependent modulation of eCB tone and the cell-specific expression of CB1, CB2, and TRVP1 provide evidence of multiple, differential eCB-dependent signaling involved in the spermatogenetic events. In mouse, decreasing levels of 2-AG have been detected from spermatogonia (SPG) to spermatocytes (SPC) and spermatids (SPT), suggesting that 2-AG, through CB2 - the receptor highly expressed just in mitotic and meiotic stages, but retained in residual body during the spermiogenesis - may act as an autocrine/paracrine mediator during spermatogenesis (73). Conversely, the high expression of Trpv1 observed in meiotic stages (73) and the massive germ cell depletion detected in Trpv1 null mice (96) candidate TRPV1 as a controller of meiotic stages. Very recently, the involvement of both CB1 and TRPV1 in the opposite modulation of testicular GnRH signaling $(15,68,97)$ a master system involved in the control of both spermatogenesis progression and steroidogenetic activity - has been reported in the anuran amphibian, the frog R. esculenta (97), a seasonal breeder in which two GnRH molecular forms (GnRH-I and GnRH-II) and three GnRH receptors (GnRH-RI, -RII and -RIII) have been characterized in testis (68). In such a context, AEA might act as an autocrine/paracrine factor via $\mathrm{CB} 1$ and as an intracrine signal via TRPV1; thus, it might be hypothesized that AEA, through the activation of specific receptors, switches on/off testicular $\mathrm{GnRH}$ signaling, leading to germ cell progression (Figure 1).

However, in mammalian and non-mammalian vertebrates, CB1 activity is linked to the control of post-meiotic stages (32, $65,69,73)$. In particular, it has been suggested that ECS controls different steps of spermiogenesis that is the phase of spermatogenesis consisting in the differentiation of SPT in SPZ. In particular, 
Table 1 | Localization of ECS components [both mRNA and protein (Prot)] in testicular somatic and germ cells

\begin{tabular}{|c|c|c|c|c|c|c|c|c|c|}
\hline Cell type & CB1 & CB2 & TRPV1 & FAAH & NAPE-PLD & MAGL & DAGL $\alpha / \beta$ & Species & Reference \\
\hline \multirow[t]{3}{*}{ Leydig cells } & mRNA & Prot & & Prot & mRNA & & & R. esculenta & $(68,69,72,79)$ \\
\hline & Prot & & & & & & & M. musculus & \\
\hline & Prot & & & & & & & R. norvegicus & \\
\hline \multirow[t]{3}{*}{ Sertoli cells } & mRNA & mRNA/Prot & mRNA & mRNA/Prot & mRNA & & & R. esculenta & $(68,70-73)$ \\
\hline & Prot & & & & & & & M. musculus & \\
\hline & & & & & & & & R. norvegicus & \\
\hline \multirow[t]{2}{*}{ ISPG } & Prot & mRNA/Prot & mRNA & mRNA & mRNA & mRNA & mRNA & R. esculenta & $(65,69,73)$ \\
\hline & mRNA/Prot & & & & & & & M. musculus & \\
\hline \multirow[t]{2}{*}{ IISPG } & mRNA/Prot & mRNA/Prot & mRNA & mRNA & mRNA & mRNA & mRNA & R. esculenta & $(65,68,69,73)$ \\
\hline & mRNA/Prot & & & & mRNA & & & M. musculus & \\
\hline \multirow[t]{2}{*}{ ISCP } & Prot & mRNA/Prot & mRNA & Prot & mRNA & mRNA & mRNA & R. esculenta & $(65,68,69,73)$ \\
\hline & mRNA/Prot & & & mRNA & mRNA & & & M. musculus & \\
\hline \multirow[t]{2}{*}{ IISPC } & Prot & mRNA/Prot & mRNA & Prot & mRNA & mRNA & mRNA & $R$. esculenta & $(65,73)$ \\
\hline & mRNA & & & mRNA & & & & M. musculus & \\
\hline \multirow[t]{3}{*}{ SPT } & mRNA/Prot & mRNA/Prot & mRNA & Prot & mRNA & mRNA & mRNA & R. esculenta & $(65,68,69,72,73)$ \\
\hline & mRNA & & & mRNA & & & & M. musculus & \\
\hline & Prot & & & & & & & R. norvegicus & \\
\hline \multirow[t]{6}{*}{ SPZ } & mRNA/Prot & mRNA/Prot & mRNA/Prot & Prot & mRNA/Prot & mRNA/Prot & mRNA/Prot & R. esculenta & $(65,68,72,78,81$ \\
\hline & mRNA/Prot Prot & Prot & Prot & mRNA/Prot & Prot & & & M. musculus & $83,84)$ \\
\hline & Prot & mRNA/Prot & Prot & Prot & & & & R. norvegicus & \\
\hline & mRNA/Prot & Prot & & Prot & & & & S. scrofa & \\
\hline & mRNA/Prot & & & Prot & & & & B. taurus & \\
\hline & & & & & & & & H. sapiens & \\
\hline
\end{tabular}

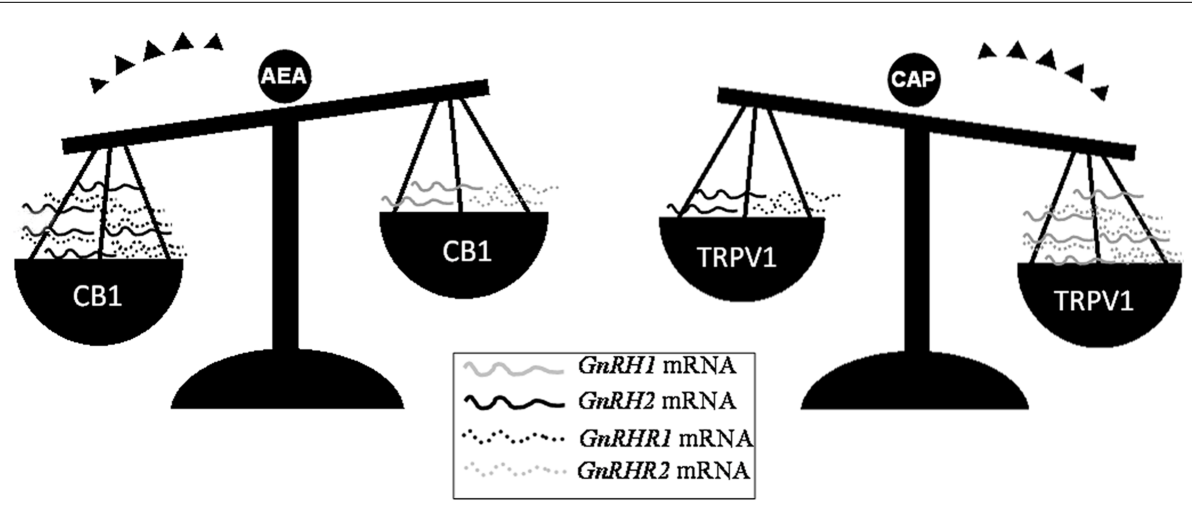

FIGURE 1 | Differential expression of GnRH system components after in vitro incubation of frog testis collected in post-reproductive periods with AEA or capsaicin (CAP), a selective agonist of TRPV1 receptor. Since intracellular AEA also bind TRPV1, the involvement of AEA in the modulation of testicular $\mathrm{GnRH}$ signaling may occur via the selective activation of different eCB receptors. post-meiotic haploid round spermatids (rSPT) undergo biochemical and morphological changes becoming elongated cells (eSPT) and then SPZ. Sperm cells are differentially released from Sertoli cells by spermiation, a process characterized by species-specific features $(65,98)$. In mammals, SPZ undergo further transformations in the epididymis, which enables SPZ for fertilization (76, 77). These cellular modifications, and in particular some structural changes observed in SPT (i.e., acrosome development, nuclear shaping and chromatin condensation), seem to be related to ECS and in particular to CB1 activity.

A detailed immunolocalization of $\mathrm{CB} 1$ has been reported in rat SPT. CB1 appears in rSPT, around the nucleus, during acrosome development; the signal is retained in the head of elongating and condensing SPT, always close to the acrosome region, suggesting a role for $\mathrm{CB} 1$ in spermiogenesis, probably in chromatin packaging and in acrosome and/or cellular shape configuration 
$(57,72,81)$. In agreement, several data demonstrate that CB1 regulates acrosome reaction, chromatin condensation, and nuclear size of SPZ $(82,99)$. Recent observations demonstrate that CB1 is involved in chromatin remodeling of SPT. In fact, during spermiogenesis, as the nucleus elongates and assumes a specie-specific shape, the chromatin condenses. It is worth noting that chromatin condensation differentially occurs, depending on the species. In mammals, chromatin condensation starts in eSPT producing condensing and then condensed SPT, which are mature elongated cells with strongly packaged chromatin (100). Many events characterize these chromatin cyto-architecture changes (101). Early during spermiogenesis, it is possible to observe the expression and storage of specific proteins involved in condensation and in DNA integrity maintenance, such as transition proteins (TNPs) and protamines (PRMs) (102). Others events concern the following: (i) displacement and degradation of the nucleosome structure; (ii) histone replacement by TNPs and then by PRMs; (iii) transcriptional silencing; (iv) DNA repair; and finally, (v) repackaging of the protaminated chromatin into toroidal structures $(103,104)$ [for recent review, see Ref. (94)]. These events strongly preserve DNA by damage and are involved in mechanism related to sperm maturation. Indeed, it is well known that inefficient expression or activity of TNPs/PRMs deranges histone displacement and causes production of SPZ with histone retention, incomplete chromatin condensation, and DNA damage $(74,105,106)$. In both humans and rodents, abnormal levels of sperm DNA damage are associated with lower conception, implantation, and fecundity rates, and with higher miscarriage probability $(95,107,108)$. In this context, Chioccarelli et al. (74) showed that $C b 1$ gene deletion negatively influences chromatin remodeling in SPT, by reducing either transition protein 2 (Tnp2) levels or histone displacement. Secondary effects, related to the inefficient histone displacement (i.e., histone retention, uncondensed chromatin, DNA damage, and nuclear size elongation) have been postulated $(22,74)$. In agreement, in vivo and in vitro experiments show that AEA is able to act locally and upregulate Tnp2 mRNA levels through CB1, via PKC/PKA pathways $(17,74)$. Furthermore, in caput epididymis from $\mathrm{CB1}^{-1-}$ mice, the percentage of SPZ retaining histones as well as the percentage of SPZ with uncondensed chromatin or with DNA damage, is higher as compared to normal mice. Interestingly, DNA damage increased during the epididymal transit, from caput to cauda, suggesting that $\mathrm{CB} 1$ preserve sperm DNA integrity of SPZ during epidydimal transit (74).

Recently, it has been demonstrated that estradiol, probably via stimulatory effects on FSH secretion and/or directly via paracrine actions within the testis, preserve chromatin condensation, and DNA integrity of SPZ, likely by promoting histone displacement in SPT (99). Indeed, it has been reported that $C B 1^{-1-}$ male mice show low levels of circulating $\mathrm{E}_{2}$, and when treated with $17 \beta$-estradiol, they rescue sperm chromatin quality by restoring histone content, chromatin packaging, DNA integrity, and nuclear length of SPZ $(22,99)$. These results corroborate the intriguing findings that the small nucleus of SPZ, containing chromatin that did not retain histones, appear fully condensed and able to preserve DNA from damage. On the contrary, the longer nucleus of SPZ, containing chromatin that retained histones, is uncondensed and unable to avoid DNA damage. The emerging exciting idea is that sperm nuclear dimensions can be a good marker for SPZ chromatin quality useful to select the SPZ qualitatively suitable for intracytoplasmic sperm injection (99).

\section{ACKNOWLEDGMENTS}

The authors wish to remember Prof. Maria Fosca Franzoni, who proficiently dedicated her life to the study of comparative neuroendocrinology. This work was supported by PRIN 2010/2011 to Patrizia Bovolin, Rosaria Meccariello, and Gilda Cobellis.

\section{REFERENCES}

1. Elphick MR, Egertová M. The phylogenetic distribution and evolutionary origins of endocannabinoid signalling. Handb Exp Pharmacol (2005) 168:283-97. doi:10.1007/3-540-26573-2_9

2. Elphick MR. The evolution and comparative neurobiology of endocannabinoid signaling. Philos Trans R Soc B Biol Sci (2012) 367:3201-15. doi:10.1098/ rstb.2011.0394

3. Mackie K. Distribution of cannabinoid receptors in the central and peripheral nervous system. Handb Exp Pharmacol (2005) 168:299-325. doi:10.1007/3540-26573-2_10

4. Cottone E, Salio C, Conrath M, Franzoni MF. Xenopus laevis CB1 cannabinoid receptor: molecular cloning and mRNA distribution in the central nervous system. J Comp Neurol (2003) 464:487-96. doi:10.1002/cne.10808

5. Cottone E, Forno S, Campantico E, Guastalla A, Viltono L, Mackie K, et al. Expression and distribution of CB1 cannabinoid receptors in the central nervous system of the African cichlid fish Pelvicachromis pulcher. J Comp Neurol (2005) 485:293-303. doi:10.1002/cne.20502

6. Van Sickle MD, Duncan M, Kingsley PJ, Mouihate A, Urbani P, Mackie K, et al. Identification and functional characterization of brainstem cannabinoid CB2 receptors. Science (2005) 310(5746):329-32. doi:10.1126/science.1115740

7. Atwood BK, Mackie K. CB2: a cannabinoid receptor with an identity crisis. $\mathrm{Br}$ J Pharmacol (2010) 160:467-79. doi:10.1111/j.1476-5381.2010.00729.x

8. Cottone E, Pomatto V, Cerri F, Campantico E, Mackie K, Delpero M, et al. Cannabinoid receptors are widely expressed in goldfish: molecular cloning of a CB2-like receptor and evaluation of $\mathrm{CB} 1$ and $\mathrm{CB} 2$ mRNA expression profiles in different organs. Fish Physiol Biochem (2013) 39:1287-96. doi:10.1007/s10695-013-9783-9

9. Di Marzo V, De Petrocellis L. Endocannabinoids as regulators of transient receptor potential (TRP) channels: a further opportunity to develop new endocannabinoid-based therapeutic drugs. Curr Med Chem (2010) 17:1430-49. doi:10.2174/092986710790980078

10. Castillo PE, Younts TJ, Chávez AE, Hashimotodani Y. Endocannabinoid signaling and synaptic function. Neuron (2012) 76(1):70-81. doi:10.1016/j.neuron. 2012.09.020

11. Ahn K, McKinney MK, Cravatt BF. Enzymatic pathways that regulate endocannabinoid signaling in the nervous system. Chem Rev (2008) 108:1687-707. doi:10.1021/cr0782067

12. Di Marzo V. The endocannabinoid system: its general strategy of action, tools for its pharmacological manipulation and potential therapeutic exploitation. Pharmacol Res (2009) 60:77-84. doi:10.1016/j.phrs.2009.02.010

13. Pertwee RG, Howlett AC, Abood ME, Alexander SP, Di Marzo V, Elphick MR, et al. International union of basic and clinical pharmacology. LXXIX. Cannabinoid receptors and their ligands: beyond CB1 and CB2. Pharmacol Rev (2010) 62:588-631. doi:10.1124/pr.110.003004

14. Piomelli D. The molecular logic of endocannabinoid signalling. Nat Rev Neurosci (2003) 4:873-84. doi:10.1038/nrn1247

15. Meccariello R, Battista N, Bradshaw HB, Wang H. Updates in reproduction coming from the endocannabinoid system. Int J Endocrinol (2014) 2014:412354. doi:10.1155/2014/412354

16. Cottone E, Pomatto V, Bovolin P. Role of the endocannabinoid system in the central regulation of nonmammalian vertebrate reproduction. Int J Endocrinol (2013) 2013:941237. doi:10.1155/2013/941237

17. Battista N, Meccariello R, Cobellis G, Fasano S, Di Tommaso M, Piazzi V, et al. The role of endocannabinoids in gonadal function and fertility along 
the evolutionary axis. Mol Cell Endocrinol (2012) 355:1-14. doi:10.1016/j.mce. 2012.01.014

18. Murphy LL, Steger RW, Smith MS, Bartke A. Effects of delta-9tetrahydrocannabinol, cannabinol and cannabidiol, alone and in combinations, on luteinizing hormone and prolactin release and on hypothalamic neurotransmitters in the male rat. Neuroendocrinology (1990) 52(4):316-21. doi:10.1159/000125604

19. Murphy LL, Muñoz RM, Adrian BA, Villanúa MA. Function of cannabinoid receptors in the neuroendocrine regulation of hormone secretion. Neurobiol Dis (1998) 5:432-46. doi:10.1006/nbdi.1998.0224

20. Scorticati C, Fernandez-Solari J, De Laurentiis A, Mohn C, Prestifilippo JP, Lasaga $\mathrm{M}$, et al. The inhibitory effect of anandamide on luteinizing hormone releasing hormone secretion is reversed by estrogen. Proc Natl Acad Sci U S A (2004) 32:11891-6. doi:10.1073/pnas.0404366101

21. Wenger T, Ledent C, Csernus V, Gerendai I. The central cannabinoid receptor inactivation suppresses endocrine reproductive functions. Biochem Biophys Res Commun (2001) 284:363-8. doi:10.1006/bbrc.2001.4977

22. Cacciola G, Chioccarelli T, Altucci L, Ledent C, Mason JI, Fasano S, et al. Low 17beta-estradiol levels in Cnr1 knock-out mice affect spermatid chromatin remodeling by interfering with chromatin reorganization. Biol Reprod (2013) 88:152. doi:10.1095/biolreprod.112.105726

23. Tsou K, Brown S, Sanudo-Pena MC, Mackie K, Walker JM. Immunohistochemical distribution of cannabinoid CB1 receptors in the rat central nervous system. Neuroscience (1998) 83:393-411. doi:10.1016/S0306-4522(97) 00436-3

24. Cota D, Marsicano G, Tschöp M, Grübler Y, Flachskamm C, Schubert M, et al. The endogenous cannabinoid system affects energy balance via central orexigenic drive and peripheral lipogenesis. J Clin Invest (2003) 112(3):423-31. doi:10.1172/JCI200317725

25. Marsicano G, Lutz B. Expression of the cannabinoid receptor CB1 in distinct neuronal subpopulations in the adult mouse forebrain. Eur J Neurosci (1999) 11(12):4213-25. doi:10.1046/j.1460-9568.1999.00847.x

26. Matsuda LA, Bonner TI, Lolait SJ. Localization of cannabinoid receptor mRNA in rat brain. J Comp Neurol (1993) 327:535-50. doi:10.1002/cne. 903270406

27. Wittmann G, Deli L, Kalló I, Hrabovszky E, Watanabe M, Liposits Z, et al. Distribution of type 1 cannabinoid receptor (CB1)-immunoreactive axons in the mouse hypothalamus. J Comp Neurol (2007) 503(2):270-9. doi:10.1002/cne. 21383

28. Meccariello R, Franzoni MF, Chianese R, Cottone E, Scarpa D, Donna D, et al. Interplay between the endocannabinoid system and GnRH-I in the forebrain of the anuran amphibian Rana esculenta. Endocrinology (2008) 149:2149-58. doi:10.1210/en.2007-1357

29. Valenti M, Cottone E, Martinez R, De Pedro N, Rubio M, Viveros MP, et al. The endocannabinoid system in the brain of Carassius auratus and its possible role in the control of food intake. J Neurochem (2005) 95(3):662-72. doi:10.1111/j.1471-4159.2005.03406.x

30. Lam CS, Rastegar S, Strähle U. Distribution of cannabinoid receptor 1 in the CNS of zebrafish. Neuroscience (2006) 138(1):83-95. doi:10.1016/j. neuroscience.2005.10.069

31. Migliarini B, Marucci G, Ghelfi F, Carnevali O. Endocannabinoid system in Xenopus laevis development: CB1 receptor dynamics. FEBS Lett (2006) 580(8):1941-5. doi:10.1016/j.febslet.2006.02.057

32. Meccariello R, Chianese R, Cacciola G, Cobellis G, Pierantoni R, Fasano S. Type-1 cannabinoid receptor expression in the frog, Rana esculenta, tissues: a possible involvement in the regulation of testicular activity. Mol Reprod Dev (2006) 73:551-8. doi:10.1002/mrd.20434

33. Chianese R, Ciaramella V, Fasano S, Pierantoni R, Meccariello R. Anandamide modulates the expression of GnRH-II and GnRHRs in frog, Rana esculenta, diencephalon. Gen Comp Endocrinol (2011) 173:389-95. doi:10.1016/j.ygcen. 2011.07.001

34. Todman MG, Han SK, Herbison AE. Profiling neurotransmitter receptor expression in mouse gonadotropin-releasing hormone neurons using green fluorescent protein-promoter transgenics and microarrays. Neuroscience (2005) 132:703-12. doi:10.1016/j.neuroscience.2005.01.035

35. Cristino L, De Petrocellis L, Pryce G, Baker D, Guglielmotti V, Di Marzo V. Immunohistochemical localization of cannabinoid type 1 and vanilloid transient receptor potential vanilloid type 1 receptors in the mouse brain. Neuroscience (2006) 139:1405-15. doi:10.1016/j.neuroscience.2006.02.074
36. Gammon CM, Freeman GM Jr, Xie W, Petersen SL, Wetsel WC. Regulation of gonadotropin-releasing hormone secretion by cannabinoids. Endocrinology (2005) 146(10):4491-9. doi:10.1210/en.2004-1672

37. Farkas I, Kallo' I, Deli L, Vida B, Hrabovszky E, Fekete C, et al. Retrograde endocannabinoid signaling reduces GABA-ergic synaptic transmission to gonadotropin-releasing hormone neurons. Endocrinology (2010) 151:5818-29. doi:10.1210/en.2010-0638

38. Cottone E, Campantico E, Guastalla A, Aramu S, Polzonetti-Magni A, Franzoni MF. Are the cannabinoids involved in fish reproduction? Ann NY Acad Sci (2005) 1040:1-4. doi:10.1196/annals.1327.041

39. Cottone E, Guastalla A, Mackie K, Franzoni MF. Endocannabinoids affect the reproductive functions in teleosts and amphibians. Mol Cell Endocrinol (2008) 286:S41-5. doi:10.1016/j.mce.2008.01.025

40. Cardinaletti G, Franzoni MF, Palermo FA, et al. Environmental and neuroendocrine control of fish reproduction. In: Garcia-Ayala A, Penalver JM, ChavezPozo E editors. Recent Advances in Fish Reproduction Biology. Kerala: Research Signpost (2010). p. 65-87.

41. Donna D, Cottone E, Aramu S, Campantico E, Guastalla A, Franzoni MF. Endocannabinoids and amphibian reproduction: an immunohistochemical study in the green frog. Accad Sci Torino Atti Sci Fis (2006) 140:37-45.

42. Herbison AE, Moenter SM. Depolarising and hyperpolarising actions of GABA(A) receptor activation on gonadotrophin-releasing hormone neurones: towards an emerging consensus. Neuroendocrinol (2011) 23(7):557-69. doi:10.1111/j.1365-2826.2011.02145.x

43. Hrabovszky E, Liposits Z. Afferent neuronal control of type-I gonadotropin releasing hormone neurons in the human. Front Endocrinol (2013) 4:130. doi: $10.3389 /$ fendo. 2013.00130

44. González S, Manzanares J, Berrendero F, Wenger T, Corchero J, Bisogno $\mathrm{T}$, et al. Identification of endocannabinoids and cannabinoid $\mathrm{CB}(1)$ receptor mRNA in the pituitary gland. Neuroendocrinology (1999) 70:137-45. doi:10.1159/000054468

45. Wenger T, Rettori V, Snyder GD, Dalterio S, McCann SM. Effects of delta9-tetrahydrocannabinol on the hypothalamic-pituitary control of luteinizing hormone and follicle-stimulating hormone secretion in adult male rats. Neuroendocrinology (1987) 46(6):488-93. doi:10.1159/000124870

46. González S, Mauriello-Romanazzi G, Berrendero F, Ramos JA, Franzoni MF, Fernández-Ruiz J. Decreased cannabinoid CB1 receptor mRNA levels and immunoreactivity in pituitary hyperplasia induced by prolonged exposure to estrogens. Pituitary (2000) 3(4):221-6. doi:10.1023/A:1012874029689

47. Pagotto U, Marsicano G, Fezza F, Theodoropoulou M, Grübler Y, Stalla J, et al. Normal human pituitary gland and pituitary adenomas express cannabinoid receptor type 1 and synthesize endogenous cannabinoids: first evidence for a direct role of cannabinoids on hormone modulation at the human pituitary level. J Clin Endocrinol Metab (2001) 86(6):2687-96. doi:10.1210/jc.86.6.2687

48. Cesa R, Guastalla A, Cottone E, Mackie K, Beltramo M, Franzoni MF. Relationships between CB1 cannabinoid receptors and pituitary endocrine cells in Xenopus laevis: an immunohistochemical study. Gen Comp Endocrinol (2002) 125:17-24. doi:10.1006/gcen.2001.7720

49. Yasuo S, Koch M, Schmidt H, Ziebell S, Bojunga J, Geisslinger G, et al. An endocannabinoid system is localized to the hypophysial pars tuberalis of Syrian hamsters and responds to photoperiodic changes. Cell Tissue Res (2010) 340:127-36. doi:10.1007/s00441-010-0930-7

50. Schuel H, Burkman LJ, Lippes J, Crickard K, Forester E, Piomelli D, et al. $N$ Acylethanolamines in human reproductive fluids. Chem Phys Lipids (2002) 121:211-27. doi:10.1016/S0009-3084(02)00158-5

51. El-Talatini MR, Taylor AH, Konje JC. Fluctuation in anandamide levels from ovulation to early pregnancy in in-vitro fertilization-embryo transfer women, and its hormonal regulation. Hum Reprod (2009) 24:1989-98. doi:10.1093/humrep/dep065

52. Gervasi MG, Marczylo TH, Lam PM, Rana S, Franchi AM, Konje JC, et al. Anandamide levels fluctuate in the bovine oviduct during the oestrous cycle. PLoS One (2013) 8:e72521. doi:10.1371/journal.pone.0072521

53. Shire D, Carillon C, Kaghad M, Calandra B, Rinaldi-Carmona M, Le Fur G, et al. An ammino-terminal variant of the central cannabinoid receptor resulting from alternative splicing. J Biol Chem (1995) 270:3726-31. doi:10.1074/jbc.270.8.3726

54. Ryberg E, Vu HK, Larsson N, Groblewski T, Hjorth S, Elebring T, et al. Identification and characterization of a novel splice variant of the human CB1 receptor. FEBS Lett (2005) 579:259-64. doi:10.1016/j.febslet.2004.11.085 
55. Liu QR, Pan CH, Hishimoto A, Li CY, Xi ZX, Llorente-Berzal A, et al. Species differences in cannabinoid receptor 2 (CNR2 gene): identification of novel human and rodent CB2 isoforms, differential tissue expression and regulation by cannabinoid receptor ligands. Genes Brain Behav (2009) 8:519-30. doi:10.1111/j.1601-183X.2009.00498.x

56. Wang H, Dey SK, Maccarrone M. Jekyll and Hyde: two faces of cannabinoid signaling in male and female fertility. Endocr Rev (2006) 27:427-48. doi:10.1210/er.2006-0006

57. Cacciola G, Chioccarelli T, Ricci G, Meccariello R, Fasano S, Pierantoni R, et al. The endocannabinoid system in vertebrate male reproduction: a comparative overview. Mol Cell Endocrinol (2008) 286:S24-30. doi:10.1016/j.mce. 2008.01.004

58. Pierantoni R, Cobellis G, Meccariello R, Cacciola G, Chianese R, Chioccarelli $\mathrm{T}$, et al. CB1 activity in male reproduction: mammalian and nonmammalian animal models. Vitam Horm (2009) 81:367-87. doi:10.1016/S0083-6729(09) 81014-5

59. Pierantoni R, Cobellis G, Meccariello R, Cacciola G, Chianese R, Chioccarelli T, et al. Testicular gonadotropin-releasing hormone activity, progression of spermatogenesis, and sperm transport in vertebrates. Ann N Y Acad Sci (2009) 1163:279-91. doi:10.1111/j.1749-6632.2008.03617.x

60. Acone G, Trabucco E, Colacurci N, Cobellis L, Mackie K, Meccariello R, et al. Low type I cannabinoid receptor levels characterize placental villous in labouring delivery. Placenta (2009) 30:203-5. doi:10.1016/j.placenta.2008.11.018

61. Trabucco E, Acone G, Marenna A, Pierantoni R, Cacciola G, Chioccarelli T, et al. Endocannabinoid system in first trimester placenta: low FAAH and high CB1 expression characterize spontaneous miscarriage. Placenta (2009) 30:516-22. doi:10.1016/j.placenta.2009.03.015

62. Cacciola G, Chianese R, Chioccarelli T, Ciaramella V, Fasano S, Pierantoni R, et al. Cannabinoids and reproduction: a lasting and intriguing history. Pharmaceuticals (2010) 3:3275-323. doi:10.3390/ph3103275

63. Chan HW, McKirdy NC, Peiris HN, Rice GE, Mitchell MD. The role of endocannabinoids in pregnancy. Reproduction (2013) 146:R101-9. doi:10.1530/ REP-12-0508

64. Ruggeri B, Soverchia L, Mosconi G, Franzoni MF, Cottone E, Polzonetti-Magni AM. Changes of gonadal CB1 cannabinoid receptor mRNA in the gilthead seabream, Sparus aurata, during sex reversal. Gen Comp Endocrinol (2007) 150:263-9. doi:10.1016/j.ygcen.2006.09.001

65. Cobellis G, Cacciola G, Scarpa D, Meccariello R, Chianese R, Franzoni MF, et al. Endocannabinoid system in frog and rodent testis: type-1 cannabinoid receptor and fatty acid amide hydrolase activity in male germ cells. Biol Reprod (2006) 75:82-9. doi:10.1095/biolreprod.106.051730

66. Meccariello R, Chianese R, Cobellis G, Pierantoni R, Fasano S. Cloning of type 1 cannabinoid receptor in Rana esculenta reveals differences between genomic sequence and cDNA. FEBS J (2007) 274:2909-20. doi:10.1111/j.1742-4658. 2007.05824.x

67. Chianese R, Cobellis G, Pierantoni R, Fasano S, Meccariello R. Nonmammalian vertebrate models and the endocannabinoid system: relationships with gonadotropin-releasing hormone. Mol Cell Endocrinol (2008) 286:S46-51. doi:10.1016/j.mce.2008.01.009

68. Chianese R, Ciaramella V, Scarpa D, Fasano S, Pierantoni R. Meccariello anandamide regulates the expression of GnRH1, GnRH2, and GnRH-Rs in frog testis. Am J Physiol Endocrinol Metab (2012) 303:E475-87. doi:10.1152/ ajpendo.00086.2012

69. Gye MC, Kang HH, Kang HJ. Expression of cannabinoid receptor 1 in mouse testes. Arch Androl (2005) 51:247-55. doi:10.1080/014850190898845

70. Maccarrone M, Cecconi S, Rossi G, Battista N, Pauselli R, Finazzi-Agrò A. Anandamide activity and degradation are regulated by early postnatal aging and follicle-stimulating hormone in mouse Sertoli cells. Endocrinology (2003) 144:20-8. doi:10.1210/en.2002-220544

71. Rossi G, Gasperi V, Paro R, Barsacchi D, Cecconi S, Maccarrone M. Folliclestimulating hormone activates fatty acid amide hydrolase by protein kinase A and aromatase-dependent pathways in mouse primary Sertoli cells. Endocrinology (2007) 148:1431-9. doi:10.1210/en.2006-0969

72. Cacciola G, Chioccarelli T, Mackie K, Meccariello R, Ledent C, Fasano S, et al. Expression of type-1 cannabinoid receptor during rat postnatal testicular development: possible involvement in adult leydig cell differentiation. Biol Reprod (2008) 79:758-65. doi:10.1095/biolreprod.108.070128

73. Grimaldi P, Orlando P, Di Siena S, Lolicato F, Petrosino S, Bisogno T, et al. The endocannabinoid system and pivotal role of the CB2 receptor in mouse spermatogenesis. Proc Natl Acad Sci U S A (2009) 106:11131-6. doi:10.1073/pnas.0812789106

74. Chioccarelli T, Cacciola G, Altucci L, Lewis SE, Simon L, Ricci G, et al. Cannabinoid receptor 1 influences chromatin remodeling in mouse spermatids by affecting content of transition protein $2 \mathrm{mRNA}$ and histone displacement. Endocrinology (2010) 151:5017-29. doi:10.1210/en.2010-0133

75. Schuel H, Goldstein E, Mechoulam R, Zimmerman AM, Zimmerman S. Anandamide (arachidonylethanolamide), a brain cannabinoid receptor agonist, reduces sperm fertilizing capacity in sea urchins by inhibiting the acrosome reaction. Proc Natl Acad Sci U S A (1994) 91:7678-82. doi:10.1073/pnas.91.16. 7678

76. Ricci G, Cacciola G, Altucci L, Meccariello R, Pierantoni R, Fasano S, et al. Endocannabinoid control of sperm motility: the role of epididymus. Gen Comp Endocrinol (2007) 153:320-2. doi:10.1016/j.ygcen.2007.02.003

77. Cobellis G, Ricci G, Cacciola G, Orlando P, Petrosino S, Cascio MG, et al. A gradient of 2-arachidonoylglycerol regulates mouse epididymal sperm cell start-up. Biol Reprod (2010) 82:451-8. doi:10.1095/biolreprod.109.079210

78. Catanzaro G, Battista N, Rossi G, Di Tommaso M, Pucci M, Pirazzi V, et al. Effect of capacitation on the endocannabinoid system of mouse sperm. Mol Cell Endocrinol (2011) 343:88-92. doi:10.1016/j.mce.2011.01.022

79. Banerjee A, Singh A, Srivastava P, Turner H, Krishna A. Effects of chronic bhang (cannabis) administration on the reproductive system of male mice. Birth Defects Res B Dev Reprod Toxicol (2011) 92:195-205. doi:10.1002/bdrb.20295

80. Gervasi MG, Osycka-Salut C, Caballero J, Vazquez-Levin M, Pereyra E, Billi $\mathrm{S}$, et al. Anandamide capacitates bull spermatozoa through CB1 and TRPV1 activation. PLoS One (2011) 6:e16993. doi:10.1371/journal.pone.0016993

81. Maccarrone M, Barboni B, Paradisi A, Bernabò N, Gasperi V, Pistilli MG, et al. Characterization of the endocannabinoid system in boar spermatozoa and implications for sperm capacitation and acrosome reaction. J Cell Sci (2005) 118:4393-404. doi:10.1242/jcs.02536

82. Schuel H, Burkman LJ, Lippes J, Crickard K, Mahony MC, Giuffrida A, et al. Evidence that anandamide-signalling regulates human sperm functions required for fertilization. Mol Reprod Dev (2002) 63:376-87. doi:10.1002/mrd.90021

83. Rossato M, Ion Popa F, Ferigo M, Clari G, Foresta C. Human sperm express cannabinoid receptor $\mathrm{Cb} 1$, the activation of which inhibits motility, acrosome reaction, and mitochondrial function. J Clin Endocrinol Metab (2005) 90:984-91. doi:10.1210/jc.2004- 1287

84. Francavilla F, Battista N, Barbonetti A, Vassallo MR, Rapino C, Antonangelo C, et al. Characterization of the endocannabinoid system in human spermatozoa and involvement of transient receptor potential vanilloid 1 receptor in their fertilizing ability. Endocrinology (2009) 150:4692-700. doi:10.1210/en.20090057

85. Amoako AA, Marczylo TH, Marczylo EL, Elson J, Willets JM, Taylor AH, et al. Anandamide modulates human sperm motility: implications for men with asthenozoospermia and oligoasthenoteratozoospermia. Hum Reprod (2013) 28:2058-66. doi:10.1093/humrep/det232

86. Darling JR, Doody DR, Sun X, Trabert BL, Weiss NS, Chen C, et al. Association of marijuana use and the incidence of testicular germ cell tumors. Cancer (2009) 115:1215-23. doi:10.1002/cncr.24159

87. Trabert B, Sigurdson AJ, Sweeney AM, Strom SS, McGlynn KA. Marijuana use and testicular germ cell tumors. Cancer (2011) 117:848-53. doi:10.1002/cncr. 25499

88. Lacson JC, Carroll JD, Tuazon E, Castelao EJ, Bernstein L, Cortessis VK. Population-based case-control study of recreational drug use and testis cancer risk confirms an association between marijuana use and nonseminoma risk. Cancer (2012) 118:5374-83. doi:10.1002/cncr.27554

89. Ayakannu T, Taylor AH, Marczylo TH, Willets JM, Konje JC. The endocannabinoid system and sex steroid hormone-dependent cancers. Int J Endocrinol (2013) 2013:259676. doi:10.1155/2013/259676

90. Lewis SE, Paro R, Borriello L, Simon L, Robinson L, Dincer Z, et al. Longterm use of HU210 adversely affects spermatogenesis in rats by modulating the endocannabinoid system. Int J Androl (2012) 35:731-40. doi:10.1111/j.13652605.2012.01259.x

91. Lewis SE, Rapino C, Di Tommaso M, Pucci M, Battista N, Paro R, et al. Differences in the endocannabinoid system of sperm from fertile and infertile men. PLoS One (2012) 7:e47704. doi:10.1371/journal.pone.0047704

92. Sun X, Wang H, Okabe M, Mackie K, Kingsley PJ, Marnett LJ, et al. Genetic loss of Faah compromises male fertility in mice. Biol Reprod (2009) 80:235-42. doi:10.1095/biolreprod.108.072736 
93. Chianese R, Ciaramella V, Fasano S, Pierantoni R, Meccariello R. Hypothalamus-pituitary axis: an obligatory target for endocannabinoids to inhibit steroidogenesis in frog testis. Gen Comp Endocrinol (2014). doi:10.1016/ j.ygcen.2014.02.010

94. Cacciola G, Chioccarelli T, Fasano S, Pierantoni R, Cobellis G. Estrogens and spermiogenesis: new insights from type 1 cannabinoid receptor knockout mice. Int J Endocrinol (2013) 2013:501350. doi:10.1155/2013/501350

95. Grimaldi P, Pucci M, Di Siena S, Di Giacomo D, Pirazzi V, Geremia R, et al. The faah gene is the first direct target of estrogen in the testis: role of histone demethylase LSD1. Cell Mol Life Sci (2012) 69:4177-90. doi:10.1007/s00018012-1074-6

96. Mizrak SC, van Dissel-Emiliani FM. Transient receptor potential vanilloid receptor-1 confers heat resistance to male germ cells. Fertil Steril (2008) 90:1290-3. doi:10.1016/j.fertnstert.2007.10.081

97. Chianese R, Ciaramella V, Scarpa D, Fasano S, Pierantoni R, Meccariello R. Endocannabinoids and endovanilloids: a possible balance in the regulation of the testicular GnRH signalling. Int J Endocrinol (2013) 2013:904748. doi:10.1155/2013/904748

98. Cobellis G, Lombardi M, Scarpa D, Izzo G, Fienga G, Meccariello R, et al. Fra-1 activity in the frog, Rana esculenta, testis. Ann N Y Acad Sci (2005) 1040:264-8. doi:10.1196/annals.1327.039

99. Cacciola G, Chioccarelli T, Altucci L, Viaggiano A, Fasano S, Pierantoni R, et al. Nuclear size as estrogen-responsive chromatin quality parameter of mouse spermatozoa. Gen Comp Endocrinol (2013) 193:201-9. doi:10.1016/j.ygcen. 2013.07.018

100. Zhao M, Shirley CR, Hayashi S, Marcon L, Mohapatra B, Suganuma R, et al. Transition nuclear proteins are required for normal chromatin condensation and functional sperm development. Genesis (2004) 38:200-13. doi:10.1002/gene.20019

101. Marcon L, Boissonneault G. Transient DNA strand breaks during mouse and human spermiogenesis new insights in stage specificity and link to chromatin remodeling. Biol Reprod (2004) 70:910-8. doi:10.1095/biolreprod.103.022541

102. Oliva R, Dixon GH. Vertebrate protamine genes and histone-to-protamine replacement reaction. Prog Nucleic Acid Res Mol Biol (1991) 40:25-94. doi:10. 1016/S0079-6603(08)60839-9

103. Rousseaux S, Caron C, Govin J, Lestrat C, Faure AK, Khochbin S. Establishment of male-specific epigenetic information. Gene (2005) 345:139-53. doi:10.1016/j.gene.2004.12.004
104. Oliva R, Castillo J. Proteomics and the genetics of sperm chromatin condensation. Asian J Androl (2011) 13:24-30. doi:10.1038/aja.2010.65

105. Shirley CR, Hayashi S, Mounsey S, Yanagimachi R, Meistrich ML. Abnormalities and reduced reproductive potential of sperm from Tnp1- and Tnp2-null double mutant mice. Biol Reprod (2004) 71:1220-9. doi:10.1095/biolreprod. 104.029363

106. Zhao M, Shirley CR, Yu YE, Mohapatra B, Zhang Y, Unni E, et al. Targeted disruption of the transition protein 2 gene affects sperm chromatin structure and reduces fertility in mice. Mol Cell Biol (2001) 21:7243-55. doi:10.1128/MCB.21.21.7243-7255.2001

107. Lewis SE, Agbaje IM. Using the alkaline comet assay in prognostic tests for male infertility and assisted reproductive technology outcomes. Mutagenesis (2008) 23:163-70. doi:10.1093/mutage/gem052

108. Hogeveen KN, Sassone-Corsi P. Regulation of gene expression in postmeiotic male germ cells: CREM-signalling pathways and male fertility. Hum Fertil (2006) 9:73-9. doi:10.1080/14647270500463400

Conflict of Interest Statement: The authors declare that the research was conducted in the absence of any commercial or financial relationships that could be construed as a potential conflict of interest.

Received: 06 February 2014; paper pending published: 14 March 2014; accepted: 31 March 2014; published online: 15 April 2014.

Citation: Bovolin P, Cottone E, Pomatto V, Fasano S, Pierantoni R, Cobellis G and Meccariello $R$ (2014) Endocannabinoids are involved in male vertebrate reproduction: regulatory mechanisms at central and gonadal level. Front. Endocrinol. 5:54. doi: 10.3389/fendo.2014.00054

This article was submitted to Experimental Endocrinology, a section of the journal Frontiers in Endocrinology.

Copyright (C) 2014 Bovolin, Cottone, Pomatto, Fasano, Pierantoni, Cobellis and Meccariello. This is an open-access article distributed under the terms of the Creative Commons Attribution License (CC BY). The use, distribution or reproduction in other forums is permitted, provided the original author(s) or licensor are credited and that the original publication in this journal is cited, in accordance with accepted academic practice. No use, distribution or reproduction is permitted which does not comply with these terms. 